\title{
GENERAL WLADYSŁAW SIKORSKI AS A PRIME MINISTER OF POLISH GOVERNMENT IN EXILE. HONEST DEMOCRAT OR HEIR OF AUTHORITARIANISM
}

\begin{abstract}
The way in which Sikorski and his policy are remembered and judged by the vast majority of Poles owes much to the legend that has surrounded him since his tragic and mysterious death and has little to do with his real accomplishments.Sikorski succeeded in passing himself off as true democrat by throwing into doubt achievements of the Piłsudski adherents and by contesting the political system they created. In truth, the Prime Minister did nothing to introduce a democratic style of exercising power. To make things worse, in the exercise of power he quite deliberately made use of the same instruments once made use of by his predecessors, thus abusing it the same way they did. One is tempted to think that Sikorski was unable to liberate himself from the influence exerted on him by Józef Piłsudski. As a Prime Minister he failed to elaborate a model of exercising power different from that established by Piłsudski whom Sikorski admired and hated at the same time. In truth, he may have considered the model elaborated by Piłsudski as ideal worth copying. But the socalled July crisis of 1940 when there took place a clash between Sikorski and Piłsudski adherents which resulted in debilitating both sides of this conflict made it necessary for Sikorski to rely for the exercise of power on cooperation with traditional political parties. AlthoughSikorski never eschewed his authoritarian tendencies, in 1940 he actually lost any chance to rise to a position once held by the Marshal Piłsudski.

Keywords: authoritarianism, democracy, politicalconflict, politicalpower, history of Poland.
\end{abstract}

Gen. Władysław Sikorski is generally acknowledged to be a symbol of the Polish democrat. The legend which has surrounded him since his tragic death, the propaganda of the years 1945-1989 and the writings of the historians deeply affected by the first two, all have combined to earn him the image of a true democrat. Characteristically enough, his biographers either attempted to reconstruct details of his life - trying, in a quite conventional vein, to present it against the background of his times - or focused mainly on elucidating military aspects of his career. However,the methods he employed in exercising power have usually been passed over in silence. The authoress of the most comprehensive study of generalSikorski sums up the life of her book`s hero in the following way:"At the age of thirty he rose to a leading position in the Polish Republic. This staggering success led him to develope a very high opinion of himself - bordering on megalomania - and his political skills. As a politician,taking little interest in theoretical deliberations, he displayed much pragmatism. He elaborated no socio-political program, which often left him dithering over what was the best line of action for him to take. His views never went

\footnotetext{
${ }^{1}$ Prof. dr hab. Arkadiusz Adamczyk, Jan Kochanowski University, e-mail: adark@interia.pl
} 
beyond some liberal bourgeois conceptions ${ }^{2}$, typical of his era, making him adhere to parliamentary centre throughout his stormy political career. An admirer of political culture of developed bourguois societies, fashioning himself into a Western-style liberal, he still remained deeply affected by the anachronistic conceptions of Polish political thought, so detached from truly democratic patterns, envisaging Poland as a world power" 3 .

This short passage - written, it needs to be emphasized,in a very peculiar period in Polish historiography - can serve as a good illustration of the consistent efforts undertaken with a view to cementing the image of Sikorski as a true democrat.In the milieu of Polish exiles the former Prime Minister was probably the only politician of note whose commitment to democratic principles was never brought into question during the era of the Polish People`s Republic - the only reservation made at that time about his political attitude was that he did not go far enough in supporting democratic agenda ${ }^{4}$.It will not be a mistake to assume that this tendency to throw into relief only some aspects ofhis lifewas a part of a greater endeavor to create an interpretation of Polish history that legitimized the Communist regime. Unlike the vast majority of the Polish émigré politicians,Sikorski - it was argued - did not exclude the possibility of coming to terms with the Soviet Union and tried to reach an agreement with Stalin (the fact which was not only regarded as an indication of Sikorski`s democratic views, but also as an evidence of his far-sightedness). What is more, he was even presented as having been willing to go so far as to recognize the right of the Russians to delimit a new and "just" boundary line between Poland and the Soviet Union - Sikorski-Majski agreement, judged in line with its Soviet interpretation, was usually adduced in proof of this willingness. One can hardly escape a conclusion herethat such a way of interpreting history was the result of a political pressure. The Communist propaganda refused to concede that Poland in whose charge remained such politicians as Raczkiewicz, Rydz-Śmigły, Sosnkowski or Składkowski ${ }^{5}$ deserved to be referred to as a democratic state.Sikorski was clearly left out of the group of politicians readily labeled as reactionary.

A strategy employed in trying to portray Sikorski as an avid democrat was very simple. All books on general Sikorski - regardless of whether they were written by those who were favorably inclined toward his policy, those who denounced it as wrong-headed, those who lived in exile or those who lived in the Polish People`s Republic - tended to share the opinion that Sikorski came to power following the bankruptcy of the authoritarian governments of "Sanacja" regime (which in the early period of the Polish

\footnotetext{
${ }^{2}$ The language used by the authoress is typical of works that appeared in print in the years 19471989. The term "bourgeois" was usually used at that time to denote Western democratic systems, while the term "democracy" referred to the so-called people`s democracies - states that remained under Soviet domination.

3 W. Korpalska, Władysław Eugeniusz Sikorski. Biografia polityczna (Władysław Eugeniusz Sikorski. Political Biography), Wrocław 1988, pp. 244-245.

${ }^{4}$ Characteristically, StanisławMikołajczyk who also as Prime Minister led the Polish Government in exile and who was even more than Sikorski willing to collaborate with Communists came to be judged by the Communist historiography much more severely. It was only the book by Andrzej Paczkowski that put quite a new slant on Mikołajczyk: A. Paczkowski, Mikołajczyk, czyliklęskarealisty (Mikołajczyk or a realist's defeat), Warszawa 1991.

5"PoradnikPropagandysty" (Self-Help Book of the Propagandist) 1946, No 3(14), p. 15
} 
People`s Republic were regarded as anti-democratic) ${ }^{6}$. The authorities whose democratic character was questioned were simply and arbitrarily assumed to have had to be automatically replaced by the ones whose commitment to democracy was in no doubt. Sikorski was looked upon just as one of the pillars of the process of democratization of Polish government.The case was made, however, that - despite his adherence to democratic principles - the full democratization of the Coalition Cabinet at whose head he stood could not be effected because of some reactionary politicians of whom the Council of Ministers was made up (its first composition included the representatives of Sanacja and after the reconstruction of the Cabinet, it was also joined by the representatives of the Polish nationalist movement).

The plane crash in which he was killed served only to enhance his reputation as a soldier-democrat. Andrzej Garlicki is right in saying that rumors about his assassination added to this democratic image ${ }^{7}$. His tragic death itself begot the rhetoric which also had a hand in creating the image. He was said to have died as servant of democracy and protector of the law and order. Such comments, especially when made by foreign statesmen, lent credence to the image of a politician allegedly committed to democratic principles ${ }^{8}$.

The perception of Sikorski had not changed after the collapse of Communism in 1989 - he was still surrounded by this democratic halo. Quite uncritically ${ }^{9}$, the democratic image was skillfully made use of in creating the Post-communist interpretation of the Polish history of the second part of the $20^{\text {th }}$ century. The portrait of Sikorski as a democrat, an advocate of national reconciliation, and a legalist was clearly in line with the interpretation of history offered and supported by the Post-communist circles. Scholars have paid little or no attention to how he came to power and what prerogatives he exercised as Prime Minister. The way in which his government was viewed and reviewed by the Polish people, both at home and in exile, has also been subject to no scrutiny.There have been no serious attempts to analyze the actions of his government in terms of their compliance with the April Constitution of 1935 . However, to neglect such analyzes was to uncritically accept the opinions held of Sikorski by his stalwart émigré adherents who either invoked the doctrine of reason of state or pointed out exceptional circumstances in which he had to act to justify all his decisions. The examination of the problems that have

\footnotetext{
${ }^{6}$ Those who criticized the pre-September ruling camp differed only on the causes of this "bankruptcy" and, depending on how they were willing to judge elites of the Sanacja regime, were convinced that changes in top leadership were necessary as those who held power had to answer for all the consequences Poland suffered as a result of the defeat in the September campaign and had to be deprived of their power as they had lost all support of the Polish society.

${ }^{7}$ A. Garlicki, „Mitomani i maniacy” (Maniacs and Mythomanias), „Polityka” No 5(31 I 2009), p. 65 .

${ }^{8}$ Sikorski`s democratic image used to be made credible by appeal to a statement President Franklin D. Roosevelt made in a posthumous recollection of Sikorski. The US President described Sikorski as a statesman committed to democratic principles.T. Panecki, Generał broni Władysław Eugeniusz Sikorski - 1888-1943 (Lieutenant General. Władysław Eugeniusz Sikorski 1888-1943), Warszawa 1993, p. 32.

${ }^{9}$ The work by Mirosław Dymarski was anexception: M. Dymarski, Stosunki wewnętrzne wśród polskiego uchodźstwa politycznego i wojskowego we Francji $i$ Wielkiej Brytanii 1939-1945 (The relations among the Polishpolitical and militaryexiles in France and Great Britain 1939-1945), Wrocław 1999.
} 
so far been ignored by scholars is more than likely to encourage inferences entirely different from those arrived at in the Communist historiography (The April Constitution of 1935 was fascist and for this reason neither Prime Minister nor government should consider themselves bound by $\mathrm{it}^{10}$ ). The reasons for so special a treatment accorded Sikorski by scholars were as follows:1) After 1989, in the process of restoring a fully sovereign state, the Polish eliteslooked backfor inspiration to the tradition of the inter-war Poland. However, the reliance on this tradition took on a peculiar quality.On one hand, there were no attempts to question the legitimacy of the system founded upon the April Constitution of 1935 - an undemocratic one - which was clearly seen in the transfer of presidential insignia by President Ryszard Kaczorowsk (President in exile) to President Lech Wałęsa, since the former`s power rested upon the Constitution just mentioned.In the task of rebuilding democracy, on the other hand, it was simply awkward to praise undemocratic system. This ambiguity manifested itself mainly in the attitude toward Józef Piłsudski. With so great a number of statues erected in his honor all over the country after 1989 , heseemed to be commemorated mainly for his activities during the years 19141920.

2) Sikorski was an historical personage who owed his entrenched image to the legend and "Gibraltar myth" that surrounded him. The fact that his cult was countenanced, not to say, encouraged during the Communist era - the proof of which can be seen in the efforts undertaken by the Communist authorities to exhume Sikorski`s body and have it reburied in Poland - contributed to creating this legend ${ }^{11}$. In the Third Republic of Poland the attempts made with a view to promotingthe image of general Sikorski satisfying all criteria of national hero were brought to a successful completion- Sikorski was buried in a crypt of the historic Wawel Cathedral on 17 September $1993^{12}$. 3) In the period 1989-1993 historical studies ofSikorski`s political activities were not as advanced as to give one a reason to challenge his commitment to democracy.

\section{THE SEIZURE OF POWER AND ITS RANGE}

In authoritarian systems power is usually assumed as a result of a coup d'etat or political instability.It was also through a coup d'etat that Józef Pilsudski rose to power in Poland in May 1926. Despite the fact that "May Victor" refused to accept attributes of

\footnotetext{
${ }^{10}$ This view was already expressed in the Manifesto issued byPKWN (The Polish Committee of National Liberation). The authors of the Manifesto simply contested the legitimacy of the April Constitution. The document published on 22 July 1944 stated: "The State National Council and the Polish Committee of National Liberation act in accordance with the Constitution of 17 March 1921 - the only legally enacted and the only biding constitution". Polska w latach 1944-1989. Dokumenty $i$ materiaty, oprac.A. Hutniewicz, A. Wątor, (Poland in the years 1944-1989. Documents and materials, ed. By A. Hutniewicz, A. Wątor), Szczecin 1988, p. 33. As a consequence, all the legal acts that derived their legitimacy from the Constitution of 1935 came to be regarded as having been invalidated (This concerned for example the act of designating President Raczkiewicz as well as the way in which the Council of Ministers was appointed). Hence, it was necessary to substitute legal government that rested its power on "lawful basis" for the one whose legitimacy rested upon "illegal" constitution.

${ }^{11}$ K. Tarka, „Rozgrywka nad trumną. Sprowadzenie prochów Władysława Sikorskiego do Polski” (A show down over the coffin. The bringing of Władysław Sikorski's mortal remains to Poland), Dzieje Najnowsze 2003, No 3, pp. 55-79.

12“"Ostatni lot” (The last flight), Polityka No 33/1889 (25, September, 1993), p. 18.
} 
power (only twice and for a brief period of time he was head of government,serving usually "only" as Minister of Military Affairs and General Inspector of the Armed Forces) there was never any doubt with whom it really lay.

General Władysław Sikorskiheaded the government twice, each time facing unusual circumstances. The first time he took the helm of the government following the assassination of President Gabriel Narutowicz.The second time in Paris, following defeat in the September Campaign in 1939 when President Raczkiewicz entrusted him with the mission of creating the government of national unity.In theory, on both occasions he seized power in a perfectly legal way.With regard to the second time, however, his coming to power can be considered to have been the result of a coup d'etat. It gave rise to a new political constellation from which Sikorski was able to derive a number of political benefits.

The events that ensued after17 September 1939 were of crucial importance for his future as Prime Minister. The Soviet Union`s entry into the territory of the Polish Republic made it necessary for the Polish authorities to abandon the country and direct the struggle from within the territory of one of the allies. In deciding to leave the country, President Mościcki - in whose hands was concentrated all power - failed to foresee that he would be deprived of the possibility to exercise his constitutional rights. Following his detention in Rumania, he had been left with no other option but to make use of one of his prerogatives and appoint his successorwho - after being sworn in - was going tostep into the shoes of the incumbent president.

Scholars diverge in their opinions about who stood behind the internment of the Polish authorities ${ }^{13}$. There is no doubt, however, that those who instigated this action wanted both President Mościcki as well as the Cabinet led by general Sławoj-Składkowski ousted from power. President Mościcki, at least during the first days of his internment was not going to make it easier for the opposition to assume power. Frompolitical scuffle which broke out over the internment of Head of State,there seemed to be emerging three possible scenarios. 1)The first scenario, opted for by the President as the best possibleunder the given circumstances, presupposed that general Kazimierz Sosnkowski would be made a formal successor of the President -the Marshal Rydz-Śmigły who had earlier been chosen

\footnotetext{
${ }^{13}$ Four different views are to be found in scholarly literature on the internment of President, the Government and the Commander-in-Chief: 1) The internment took place on the independent initiative taken by the Romanian government (this view is adhered to by very few scholars); 2) The internment was a result of the pressure exerted by both German and Soviet authorities; 3 ) it is some French political circles known for wielding much influence in Romania and for being unfavorably disposed to the Piłsudski ruling camp that are to blame for detaining the Polish President and the Government; 4) it is the Polish opposition that stood behind the internment of the representatives of the Piłsudski regime. For more on the problem of the internment and particularly on the part Sikorski played in it see: A. Cienciała, "Jak doszło do internowania rządu w Rumunii we wrześniu 1939" (How did the internment of Polish authorities in Romania in September 1939 come about?), Niepodległość 1989, No XXII, p. 45; M. Dymarski, op. cit., pp. 27-31; For different views on the problem see also: E. Duraczyński, Rząd polski na uchodźstwie 1939-1945 (The Polish government in exile 1939-1945), Warszawa 1993, p. 33 and next; T. Wyrwa, Odbudowa władz Rzeczypospolitej w Paryżui Angers, wrzesien 1939-czerwiec 1940(The rebuilding of the Polish authorities in Paris and Agners, September 1939-June 1940) [w:] Władze polskie na obczyźnie podczas II wojny światowej (The Polish authorities in exile during the Second World War), ed. By Z. Błażyński, London 1994, pp. 12-31.
} 
as the President's formal successor suffered the same fate of internment. Then, Sosnkowski was to form his own Cabinet whose policy was to be left entirely to his discretion. Mościcki, however, did not decide to pursue this scenario, since he did not knowSosnkowski`s whereabouts. It was feared that Sosnkowski may have failed to leave the country and would notfor this very reason be able to take upon himself the task which he was to be entrusted with. 2) The second one which was also endorsed by the President -who, however, regarded it as only a temporary solution - presupposed that at least as long as Sosnkowski`s ability to play any political role remained uncertain, the power would pass togeneral Bolesław Wieniawa-Długoszowski, the Polish Ambassador to Rome.Wieniawa-Długoszowski even managed to take up presidential powers and entrust the PrimateAugust Hlond with the mission of creating a new Cabinet. This plan, however, was thwarted by France's unprecedented interference in the Polish affairs ${ }^{14}$. 3) The third scenario was endorsed by the opposition. According to it, the Polish pre-war opposition was to call for presidency to be offered toIgnacy Paderewski who in turn was to designateSikorski as Prime Minister ${ }^{15}$. With no party capable of carrying through their own plan, this political haggling ended in a compromise. The position of future president, now to be appointed by the incumbent president - Mościcki decided to choose as his successor Władysław Raczkiewicz, the former Speaker of the Upper Chamber of the Polish Parliament - was to be offset by that of Prime Minister whose office was finally taken by Sikorski ${ }^{16}$.

Taking charge of the government was Sikorski`s first step in his efforts to remove the members of Sanacja regime from power.If primary sources give us no ground to believe that Sikorski, prior to his nomination for the post of Prime Minister, was seized with a lust for power and was determined to secure for himself the position of chief of government ${ }^{17}$, then his later activities allow us to argue that he set about building a political system which had little in common with democratic principles, allegedly adhered to by Sikorski. The establishment of the chancellor system of government under the given circumstances required three things. 1) The undermining of the position of the President which under the April Constitution of 1935 was very strong. 2) The depriving ofthe head of state of the very possibility of building a reliable and active powerbase. 3) The concentrating of as large a share of power as possible. One way or another, any attempt to establish authoritarian system of government had to result in a conflict with Raczkiewicz. The personality clash was likely to end up in Sikorski`s victory. Younger than the Prime

\footnotetext{
${ }^{14}$ The French Prime Minister M. Daladier stated in a note to the Polish ambassador J. Lukasiewicz that the French authorities having no confidence in B. Wieniawa-Długoszowski find it impossible to recognize the government headed by general Wieniawa, quoted from: W. Pobóg-Malinowski, Najnowsza historia poolityczna Polski. Okres 1939-1945 (Modern political history of Poland. The period 1939-1945), Vol. 1, Gdańsk 1989, p. 87.

${ }^{15}$ S. Stroński, „I. Paderewski - śmierć na posterunku” (I. Paderewski - A line of dutydeath) Dziennik Polski i Dziennik Żotnierza, London, No 160 (6 July 1951), p. 3.

${ }^{16}$ Some aspects of the September crisis were to be repeated later in the period of transition from Communism to democracy. 50 years later power struggle came to be accompanied by a sloganyour President, our Prime Minister see: A. Michnik, "Waszprezydentnasz premier" (Your President, our Prime Minister), Gazeta Wyborcza, No 40 (3 July 1989), p. 1.

17 M. Dymarski, „Notatnik rumuński gen. Władysława Sikorskiego, wrzesień 1939” (Gen. Władysław Sikorski`s Romanian Notebook, Septemeber 1939), Teki Historyczne 1999, Vol. XXII, pp. 266-271.
} 
Minister, the Presidentwas a civil servant type rather than a political animal, with no reputation for coping with multidimensional conflict ${ }^{18}$. Besides, his political decisions were affected by his illness (leukemia) which, since it was progressing, actually eliminated him from political life. With the President no longer able to play an active role in the affairs, the position of Prime Minister - regardless of who was going to hold the office - grew in importance. Impelled by ambition and more active than the President, Sikorski took every advantage of the situation he was in to achieve his goals - the fact unanimously stressed by all his biographers.

The view commonly held by scholars is that the Paris Agreement ledSikorski to concentrate in his hands executive powers vested in Prime Minister and the Commanderin-Chief. The books on military history indicate that Sikorski as head of government also supervised all military matters. The thing which is usually left out of all discussions on the general is the fact that he was also in charge of the Ministry of Internal Affairs and the Ministry of Justice. First of all, it needs to be stressed that one was to be allowed to exercise the function of Prime Minister and that of Commander-in-Chief only for a limited period of time. Raczkiewicz, however, made a mistake by failing tospecify precisely the length of time after which Prime Minister was to be required to renounce one of the two functions.

There are three conclusions to be drawn from the new situation which had arisen. 1) Prior to the outbreak of the Second World War there was no politician in Poland who would have been able to concentrate in his hands as great a power as that held by Sikorski. 2) The goal which he had in mind when he decided to take charge of all key ministries in his Cabinet was to provide himself with the possibility of using state apparatus in the struggle with the President and the opposition of the members of the pre-war regime whose influence he wanted to eliminate.His promise to give up the command of the army the moment there had appeared in exile an officer who outranked him and could thus replace him as commander-in-chief was not kept ${ }^{19}$. 3)Although he had no powerbase to rely on for the execution of any political plan, it was already in September 1939 that he decided to embrace the authoritarian system of government - with himself, of course, calling the tune.

Scholars have usually followed very specious interpretation in presenting his internal policy - the one which did not concern Poland`s relations with other powers - making no attempt to specify the goals it was supposed to achieve. To reveal the goals Sikorski set himself would be to sully his reputation as a democrat. The general, however, right after he had come to power - himself or through the assistance of those on whose support he could rely - took three steps clearly designed to cement his leading position in the Polish politics of the time. 1) He succeeded in divesting the president of the ability to exercise some of the prerogatives vested in head of state. 2) He took an effort to make sure that he

\footnotetext{
${ }^{18}$ In 1930 the Marshal Piłsudski was to judge Raczkiewicz in the following way:He would make a good voivode. He would also be a good Minister of Internal Affairs, but only in the period troubled by no serious political difficulties. He lacks the spine. Quoted from: W. Pobóg-Malinowski, op. cit., p. 87.

${ }^{19}$ Dyplomata $w$ Paryżu. Wspomnienia $i$ dokumenty Juliusza Łukasiewicza, ambasadora Rzeczypospolitej Polskiej (Diplomat in Paris. The recollections and documents of Juliusz Łukasiewicz, Ambasador of the Polish Republic), ed. by W. Jędrzejewicz, H. Bułhak, London 1989, p. 410.
} 
would succeed Raczkiewicz as President.3) he initiated the action calculated to get rid of some of the constitutional organs that could limit Prime Minister`s power. All these moves were of course presented as having been taken with a view to making the system more democratic than that left behind by Sanacja regime.

It was with the so-called Paris agreement, signed andput into effect on 30 September 1939 that Sikorski came to be allowed to influence the way in which some of the presidential prerogatives were to be exercised. Affected by democratic sentiments which seemed to be sweeping over the Polish society, Raczkiewicz released a statement in which he agreed to consult the Prime Minister for the exercise of some of his prerogatives, even though the April Constitution did not require him to do so. One, however, was not justified in treating the statement as announcing a formal agreement which the President decided to sign with the Prime Minister and which was legally binding on him. It was nothing but an expression of the President's good will. In the slightly changed circumstances, however, on 9 December the statement was publishedin "Monitor Polski". The decision to publish the President's political declaration in the organ which served at the time as "Dziennik Ustaw" (Journal of Laws of the Republic of Poland) - which, it is worthy of mention, was in violation of the Constitution ${ }^{20}$ - was calculated to turn the President's statement into a formal interpretation of the Constitution ${ }^{21}$, thus making it a legal act which the President was required to follow in the exercise of his power. "The Paris agreement" and the way in which it was used often drove a wedge between Polish politicians in exile, provoking much strife and dissentions ${ }^{22}$. There is no doubt, however, that it was the Prime Minister who was going to reap benefits from the state of affairs which had begun to emerge towards the end of $1939^{23}$.

The next step was designed to enable Sikorski - at leastin the long run - to rise to presidency. As long as the office was exercised by Raczkiewicz who displayed little or no great political ambitions, Sikorski had no reason to worry about having his power limited to any serious extent. With the office, however, going to someone seized with political ambitions and gifted with political skills, Sikorski`s position was likely to be

\footnotetext{
${ }^{20}$ It is this article of the Constitution that vested in the President uniform and undivided state power.

${ }^{21}$ For more on the problem see: W Rostocki, Stosowanie Konstytucji Kwietniowej w czasie II wojny światowej (The application of the April Constitution during the Second World War), Lublin 1988.

${ }^{22}$ The most serious trial of strength in the interpretation of the Paris Agreement took place during the crisis of 1947. Without consulting the Prime Minister, the dying President W. Raczkiewicz designated a new person to succeed him in the office of President, which had the effect laid down in the Article 24 of the Constitution. See: R. Habielski, Kryzysy polityczne 1947 i 1954 (Politicalcrises of 1947 and 1954), [w:] Warszawa nad Tamiza. Z dziejów polskiej emigracji politycznej po II wojnie światowej (Warsaw on the River Thames. The history of the Polish political emigration after the Second World War), ed. by A. Friszke, Warszawa 1994, p. 26. P. Skrzynecki (L. Brzoza), „Kiedy umierał prezydent Raczkiewicz” (When the President Raczkiewicz was dying), Zeszyty Historyczne 1989, No 87, pp. 3-16.

${ }^{23}$ WładysławRostocki maintains that it was Stanislaw Stroński - acting in Sikorski`s favor - who drafted "the Paris Agreement". He also argues that Sikorski decided to accept the post of Prime Minister once he learned that "the Paris Agreement" Stroński had prepared was supposed to enable Prime Minister to conduct policy which President would not be able to interfere with. See: W.Rostocki, Pięćdziesiąt pięć lat mocy obowiąującej konstytucji kwietniowej. Ustrój władzy państwowej $w$ ustawie zasadniczej $i$ praktyce (Fifty five years of the operation of the April Constitution. The system of state authorities in the Basic Law and in practice), Lublin 2002, p. 103.
} 
undermined.Sikorski knew that turning the Paris Agreement into an official and legally bidding document - and such attempts were made - would not be enough to offset the influence of new president. Hence, at the turn of September and October of 1939 the pressure was applied onRaczkiewicz who was urged to appoint - in accordance with the article 24 of the Constitution - Sikorski as his successor. Raczkiewicz, however, showed some dexterity in dealing with the whole thing. At first, he was slow about making his decision, since he wanted to see - that is at least how he justified his action - if the nomination could be expected to go down well with those Polish politicians who still stayed in Poland. He also did not try to conceal his reluctance to nominate as future president the person who not only exercised the office of Prime Minister but also served as Commander-in-Chief. Finally, he decided to designate general K. Sosnkowski as a future president, ignoring the accusations that in doing this he broke the Paris Agreement (the nomination was announced in the Monitor of Poland on the October the thirteenth). Undoubtedly, the Prime Minister must have regarded the appointment of Sosnkowski as his political failure. It led him to make an attempt at neutralizing or even eliminating his new opponent.Sikorski renounced his position as Commander-in-Chief, to be filled now by Sosnkowski - this renunciation was a step which he was required to take following the previous agreement.But he also put Sosnkowski in charge of one of the ministries in his government, thus in fact significantlyreducing the latter's control of the army. What is more, in his capacity as ministerSosnkowski was to oversee the exchange of information with the occupied Poland, the task which he was supposed to discharge along withStanisław Kot. As a result, he got himself entangled in competence disputes. If the Prime Minister intended to make Sosnkowski struggle with problems of secondary importance, which of course had to result in curtailing the latter`s chances to gain more political influence (leaving aside the fact whether Sosnkowski was willing to vie with the Prime Minister for power), then he can be considered to have achieved his goal ${ }^{24}$.

Sikorski and his followers also made an attempt to prevent parliament from exercising effective control of the government andfrom applying the article 31 section 2 of the Constitution $^{25}$. Pressed by the pre-war opposition which called for realizing "the idea of national unity", the President decided to dissolve the Parliament on2 November 1939. In doing this Raczkiewicz deprived himself of the possibility of applying the article 71 section 2 of the Constitution which allowed the Parliament to perform its function. The National Council, brought into being on 2 December 1939 was supposed to serve as a stopgap for the dissolved parliament ${ }^{26}$. Leaving aside the fact that no representative of the

\footnotetext{
${ }^{24}$ M. Pestkowska, Kazimierz Sosnkowski, Wrocław 1995, pp. 89-90.

${ }^{25}$ The fragment of the Constitution under discussion was framed in the following way: Control over the exercise of power by the government manifests itself in the Seym`s right to: a) call for the resignation of the government or Minister; b) bring Prime Minister or other Ministers to account for their actions; c) interpellate the government; d) approve of the audit of government expenditure and give the government vote of approval; e) participate in the exercise of control over state debts.

${ }^{26}$ An expert on the history of the Polish parliament in exilemaintains that: the Council was an advisory body holding little significance in the structure of the Polish state in exile. It was President who was to create the Council out of distinguished politicians representing main political parties and staying in France or in one of the neighboring countries - but he was to do so at the instance of Prime Minister. At first (1939-1940) the council was made up of a dozen or so members and later beginning with 1942 - included several dozen men. The role to be performed by the council never changed, since the body was not brought into being by elections. The latter could not be held during
} 
pre-war ruling elite was offered a place in the Council, the body could not be regarded as politicallyrepresentative, since it included no members of national minorities inhabiting Poland prior to the outbreak of the war, which - considering the need to counteract the propaganda of the Stalinist Russia - was a mistake ${ }^{27}$. This is a clear argument - and not the only one - that the idea of national reconciliation was nothing but a façadedesigned to hide the intention of remodeling the Polish political system ${ }^{28}$. The attempts made at the turn of 1939-1940 to solidify the authoritarian system can hardly be accounted for by the need to preserve the legal continuance of the Polish state or by the commitment to adhere to the principles inherent in the April Constitution thought of as ruling out any other alternative solutions.

\section{BETWEEN TWO FORMS OF AUTHORITARIANISM}

There is no doubt that neither Sikorski nor those connected with him - except for their ambition to maintain power - had a political program to follow in building a future Polish state once the war was over. The reasons for this were twofold 1) During the ascendancy of the Piłsudski adherents in the inter-war period, the main goal to be pursued by the opposition confined itself toousting the former from power, 2) Following defeat in the September campaign, at the turn of September and October of 1939, no leader of the prewar opposition could have aspired to play a role of the ideologist of the new authorities. Hence, the government had been left with no other option but to rely for their state philosophy on concepts and ideas developed in the milieu of the Piłsudski adherents prior to the outbreak of the war $^{29}$. No attempts were made at redefining the essence of state and its ethical foundations. State was still regarded as an independent and objective being, endowed with its own consciousness, following its own laws and moral principles. The latter were not born out of parliament's legislative activity but were considered as transcendent and eternal ${ }^{30}$. Although the new ruling camp declared the advocacy of the

the war and in exile. R. Turkowski, Parlamentaryzm polski na uchodźstwie 1945-1972 w okresie rozbicia emigracji politycznej w Londynie (The Polish parliamentarism in exile 1945-1972 during the disunity in the Polish political emigration in London), Warszawa 2006, p. 6.

${ }^{27}$ It was already in a diplomatic note dispatched by the People`s Commissar for Foreign Affairs Wiaczesław Mołotow to the Polish Ambassador to Moscow on 17 September 1939 that the Soviet Union assigned itself the role of acting as protector of Slav minorities oppressed by the Polish state.The note read as follows:We cannot remain indifferent when our brothers Ukrainians and Belorussians in whose veins flow the same blood as ours and who live in Poland are left to their fate entirely unprotected.

${ }^{28}$ According to A. Grzywacz and M. Kwiecień criteria followed in electing members to the first National Council were political with candidates judged by their attitude towards Prime Minister coming to the fore. This can account for the eager reliance in filling the Council upon those who had ties to Front Morges before 1939. Government agencies in charge of the evacuation of Poles to France took care to pick out all loyal political personages enabling them to reach their destination while trying to make it difficult forthose whose loyalty was in doubt.A. Grzywacz, M. Kwiecien, „Rada Narodowa Rzeczypospolitej Polskiej w walce z sanataorami 1939-1941” (The National Council of the Polish Republic in its struggle against the representatives of the Sanacja Regime 1939-1941),ZeszytyHistoryczne2000, Vol. 131, p. 9.

${ }^{29}$ For more on the problem of ideological dimension of the authoritarian system created by the Piłsudski adherents see: W. Paruch, Myśl polityczna obozu Piłsudczykowskiego 1926-1939 (Political thought of the Piłsudski camp 1926-1939), Lublin 2005, pp.215-217.

${ }^{30}$ Ibidem, p. 215. 
idea of state as sovereign being pursuing its own particular interests (the reason of state), it actually moved far away from all ideas concerning the nature of state, adhered to among the Piłsudski supporters. The slogans of "political realism"and the emphasis put upon the necessity to abandon Beck's policy of overweening ambitions in foreign policy stood in stark conflict with the viewadvocated by the Piłsudski adherents that a sovereign state is supreme being whose supremacy must remain unchallenged (Sikorski`s government was clearly guilty of violation of the idea of sovereignty by yielding to the British pressure concerning the way in which Poland should shape her relations with the Soviet Union).Sikorski and his supporters also followed the Piłsudski adherents in regarding state as a vehicle for shaping public life and promoting specific social values. In this regard, however, the only thing they seemed to achieve was to draw a sharp contrast between a "good society" and evil members of the Piłsudski camp -the latter held responsible for turning Poland into a Fascist-style stateand bringing about a resounding defeat Poland suffered in the September of $1939^{31}$. Following this line of reasoning, Sikorski and his supporterscontested the conviction that the elites connected with Pilsudski should be recognized as having made the main contribution to the rebirth of an independent Poland in 1918. Whilethe Piłsudski adherents did not deserve to be given credit for restoring an independent Poland in 1918, they certainly could be to blame for her fall in 1939. This criticism came to be supplemented by the belief that the creation of the new Poland, the one to be emerged from the war, could be effected by nobody but the members of the new ruling camp gathered around the Prime Minister and the Commander-in-Chief of the Polish army.The rejection of Piłsudski`s legacy was also clearly seen in repealing the law of 7 April 1938 - the Protection of Good Name of Marshal Pitsudski Bill ${ }^{32}$.

Sikorski also to a great extent relied on his predecessors for policy making model. He believedit is the past that needs to be turned to for knowledge concerning political activity. He was also convinced the main goal of this activity was to be aimed at defeating politicalopponents ${ }^{33}$, whichled him to consider the task of removing all members of "Sanacja" regime from political life as one of the key goals to be pursued in his political activity. In Sikorski`s opinion the Piłsudski adherents, still able to exert some influence upon the President, were to pose the most serious threat for his position. The struggle against the Sanacja Regime allowed the pre-war opposition to become consolidated and united around the Prime Minister. The belief that it was necessary to jettison allSanacja

\footnotetext{
${ }^{31}$ Sikorski blamed the Piłsudski adherents for a resounding defeat in the September campaign in a letter he wrote to his predecessor in office. See: A. Adamczyk, Generat dywizji Stawoj Felicjan Składkowski 1885-1962. Zarys biografii politycznej (Major general. Sławoj Felicjan Składkowski 1885-1962. The outline of politicalbiography), Torun 2001, pp. 282-283; M. Sioma, Felicjan Stawoj Składkowski. Żotnieżi polityk (Felicjan Sławoj Składkowski. Soldier and politician), Lublin 2005, p. 403.

${ }^{32}$ In an effort to justify the motion its proponent colonel IzydorModelski said that the statute is derived from totalitarian theories that elevate individual above the nation. Neither in the past nor in the present can its legitimacy be found. It is an anomaly and as such needs to be repealed. Archiwum Instytutu Pamięci Narodowej w Warszawie. Rząd polski na emigracji, MBP, t. 242 (The Archive of the Institute of National Remembrance in Warsaw, The Polish government in exile, MBP, Vol. 242), Korespondencja gen. do zadańspecjalnych Naczelnego Wodza I. Modelskiego z Prezesem Rady Ministrów, 1941 (The correspondence of the special task general I. Modelski affiliated with the Commander-in-Chief with Prime Minister, 1941).

${ }^{33}$ W. Paruch, op. cit, p. 122.
} 
legacy served as a convenient justification for leaving some important aspects of both domestic and foreign policy entirelyneglected.

In the initial stage of exercising his office, Sikorski - following the example of his predecessors - upheld the division of policy making model into two parts: the first one which can be referred to as directive involved plans and arrangements that came directly from the general's office, and the second one called non-directive bound up with some political issues which were not directly supervised by the Prime Minister. Sikorskiupon taking the helm of the government endowed himself with prerogative powers much wider than those enjoyed by Piłsudski (which is clearly indicated by a number of resorts in whose personal charge he remained and which can also be clearly seen in the comparison with the formal scope of power held by Piłsudski right after he carried out the coup detat in May 1926.)

Sikorski`s attitude towards the law was also the same as that which characterized the Piłsudski adherents. This was reflected 1) in the Machiavellian treatment accorded the law by the representatives of the new ruling camp in spite of the fact that the Prime Minister tried to pass himself off as a guardian of the idea of the rule of law; 2) in allowing for the possibility of using extra-legal means (especially in the political struggle); and 3) in the use of the existing laws in a way which was out of keeping with the intentions of those who created them $^{34}$ - the practice which was also patterned after the one used by the Piłsudski adherents.Such an approach had the effect of making the political struggle assume an obliterating character. It suffices to mention that in trying to get rid of the threat - whether it was real or imaginary - posed by Sanacja, the same methods were used as those used by Sanacja itself in the years 1926-1939.

\section{THE ELIMINATION OF POLITICAL OPPONENTS}

Of course, formally the representatives of the new ruling camp declared to have droppedthe methods once employed by the Sanacja regime. With suspicious circumstances surrounding the death ofgeneralWłodzimierz Zagórski ${ }^{35}$, with general Jordan-Rozwadowski suffering from sudden health problems(which resulted in his death $)^{36}$, withWojciech Korfantymeeting the same fate, and with a variety of other episodes taking place in the pre-war period, one was supposed to have no difficulty in discerning both the pathological character of thecriminalregime ${ }^{37}$ as well as the need to deprive the remaining adherents of the Marshal Piłsudski of any influence on public life.

\footnotetext{
${ }^{34}$ Ibidem, p. 183.

35 Z. Cieślikowski, Tajemnice śledztwa KO 1042/27. Sprawa generała Włodzimierza OstoiZagórskiego, (The secrets of investigation KO 1042/27. The case of gen. Włodzimierz OstojaZagórski), Warszawa 1997, passim; P. Kowalski, Generał brygady Włodzimierz Ostoja-Zagórski 1882-1927. Biografia, (Brygadier General Włodzimierz Ostoja-Zagórski 1882-1927. Biography) Toruń 1997, p.127.

${ }^{36}$ For more on the problem see: M. Patelski,Generat broni Tadeusz Jordan-Rozwadowski. Żotnierz i dyplomata (Lieutenant General Tadeusz Jordan Rozwadowski. Soldier and dyplomat), Warszawa 2002 , p. 3112.

${ }^{37}$ Formulation derived from: the Archives of the Polish Institute and Sikorski Museum in London [henceforward IPSM], The Ministry of Justice, sign. A20.5/16,s.pZeznania Zbigniewa Korfantego przed Komisja dla rejestracji faktów i zbierania dokumentów dotyczacych przebiegu ostatnich zdarzeń $w$ Polsce (Zbigniew Korfanty`stestimonybefore the Fact Finding Commission to Enquireinto Recent Events in Poland).
} 
That it should be treated as a justified goal to be pursued by Sikorski and his followers in their political struggle was repeated in their propaganda with the same frequency as the opinion that the Piłsudski adherents were to blame for the defeat suffered by Poland in the September campaign.These questions were raised by the Fact Finding Commission to Enquire into Recent Events in Poland ${ }^{38}$. It needs to be stressed that at the turn of 1939/1940 the strife which had been sweeping across the Polish political arena showed no sign of relenting and the analysis of the political situation given by the new ruling elite pointed out that the Third Reich and the Soviet Union were not always defined as likely to remain Poland`s main enemies for the rest of the $w^{39}{ }^{39}$. The decisions then taken make it quite clear that such a view was also shared by Sikorski who kept receiving unconfirmed reports concerning the alleged re-emergence of military structures of POW (The Polish Military Organization led by Piłsudski during the First World War) ${ }^{40}$. It was this rumors that led Sikorski to decide to remove the leader of the home underground movement,general MichałTokarzewski-Karaszewicz, from his position ${ }^{41}$. Officially, the organizer and commander of the Service for Poland`s Victory (the organization which was the precursor to the Union for Armed Struggle and the Home Army)TokarzewskiKaraszewicz was slated to become commander-in-chief of the Polish clandestine movement under Soviet Occupation.However, to send to Lviv a soldier who served there before the war as a commanding officer of the Corps area (okręg korpusu) and whose face was instantly recognizable there was to attempt to eliminate him $^{42}$. Thecase of

\footnotetext{
${ }^{38}$ IPMS, The Ministry of Justice, sign. A 20.5/16, s.p.

${ }^{39}$ In one of the documents potential enemies were identified as follows: Warsaw: the enemy number 1 - Sanacja regime, the enemy number 2 -germans (sic!), the enemy number 3 - Bolsheviks; Lviv: the enemy number 1 - Bolsheviks, the enemy number 2 - Sanacja regime, the enemy number 3 germans (sic!); Cracov: the enemy number 1 - germans (sic!), the enemy number 2 - Sanacja regime, the enemy number 3 - Bolsheviks: IPSM, Prezydium Rady Ministrów sygn. 24/1, Raport nt. Sytuacji ogólnopolitycznej w kraju (the Meeting of the Cabinet of Ministers, sign. 24/1, The report on the political situation in Poland) 18 February 19490.

${ }^{40}$ Stefan Rowecki w relacjach (Stefan Rowecki remembered by others), ed. by Tadeusz Szarota, Warsaw 1988, pp. 152-153.

${ }^{41}$ D. Bargiełowski, Po trzykroć pierwszy. Michat Tokarzewski-Karaszewicz. Generał broni. Teozof. Wolnomularz. Kapłan Kościoła Liberalno-katolickiego (Three Times the First. MichałTokarzewskiKaraszewicz. Lieutenant General. Theosopist. Freemason. The Priest of the Liberal-Catholic Church), Warsaw 2001, p. 300 and next.

${ }^{42}$ Józef Garliński one of the apologists for Sikorski’s policy put things straightforwardly: it was a very unfortunate decision. Before the outbreak of the war general Tokarzewski served in Lviv as a commanding officer of the Corps area and every child knew him very well so there was no doubt that the NKVD would capture him in next to no time. [J. Garliński, Politycy I żołnierze (Politicians and soldiers), Warsaw 1991, p. 39.] Actually, General was not even able to take up the post to which he had been appointed. He was arrested by Russians while he was trying to cross the River San. In defiance of those who put forward the idea of appointing him to the position in question and sending him to death, General managed to survive, being released from the Lubianka prison on 17 August 1941. One of the officers of the Polish army commented upon the case of Tokarzewski in the following way: His fate as the commander-in-chief of the Polish underground organization was decided at the highest level. Several factors added up to this. Most important seemed to be the fear that the country was likely to come under control of the Sanacja elements which according to high new government officials had already contrived to establish themselves at the head of the home underground organization (...) General Tokarzewski was perceived by Paris as a symbol of the
} 
Karaszewicz was not an isolated one. It was one given much publicity simply exemplifying devious methods used by the government in removing high rank officers considered as political opponents. But for the fact that Karaszewicz had managed to survive the Soviet Gulag, he would have become the symbol - comparable at least to that of T. Jordan-Rozwadowskiego - of an officer exterminated for purely political reasons.

Law Giving Way To Lawlessness. "Kondemnatki" and the Proceedings of the FactFinding Commission to Enquire into Recent Events in Poland and the Registration Office in the Ministry of Military Affairs.

Declaring adherence to the rule of law asthe most fundamental principle to be followed in the exercise of power did not prevent the followers of both Piłsudski and Sikorski from employing extra-legal methods. Leaders of both camps either had recourse to extra-legal means or at least approved of the extra-legal actions carried out by others. It can certainly be said of some actionstaken by Piłsudski and Rydz-Śmigły in the years 1926-1939 as well asof those taken by Sikorski during the Second World War. The most spectacular example of such an extra-legal activity in the inter-war period was the Brest trial ${ }^{43}$. It had served as a symbol of such a devious approach to law, especially since general SławojSkładkowski had divulged in his memoirs that it was Piłsudski`s own initiative to accept a strategy allowing those in power to bend the rules whenever it was found convenient and suited their interests. The trial itself which came to be regarded by many as a travesty of justice ${ }^{44}$ was used as a tool with which to remove from political life some members of the opposition

In Paris Sikorski and his followers drew on the same mechanism in dealing with the opposition. Premier de facto decided on the personal implication of his political opponents, not doing, moreover, from the fact that a greater mystery ${ }^{45}$.The extent of

Sanacja regime although all his reports and statements clearly condemned the pre-September system. Studium Polski Podziemnej w Londynie, Kol. Płk Franciszka Demela, sygn. 11/18, k. 1113. Opracowanie ppłk dypl. Józefa Mateckiego dotyczace poczatków ZWZ (The Polish Underground Study Trust in London. The Collection of Lieutenant Colonel Franciszek Demel, sign. 11/18. Materials on the beginnings of ZWZ prepared by Lieutenant Colonel JózefMatecki).

${ }^{43}$ As the general wrote: The Commandant coined the term , kondemnatki" to be used for describing how far particular members of parliament laid themselves open to various charges. He urged me to fill him in on all the details of charges brought against MPs`of Centrolew. F. S. Składkowski, Strzępy meldunków (The scraps of reports), Warsaw 1988, p.97. A few days later the general noted: On the list of MPs`I gave him the Marshal marked with a green pencil those who were going to be arrested and imprisoned in Brześć. Ibidem, p. 104.

${ }^{44}$ It was as early as 1940 that people who surrounded Sikorski issued a publication (the London edition 1941) designed to present Brześć as an instrument of political struggle. The Brześć affair, (London 1941, pp. 247). According to Adam Pragier, two former prisoners of Brześć detention camp were entrusted with the task of preparing the publication; socialist politician Herman Liberman and Karol Popiel. The latter was linked to Sikorski and represented Christian Democratic Party. However, Sikorski`s coterie could be charged with relativism. On one hand, for propagandistic purposes the adherents of Prime Minister declared themselves opposed tothe methods used by representatives of the Sanacja regime, but on the other they did not hesitate to employ the same methods in trying to eliminate them from political life.

45 IPMS, Prezydium Rady Ministrów (Inner Cabinet Meeting), sign. 6/a Korespondencja Wodza Naczelnego z członkami b. rządu (The Commander-in-Chief s Correspondence with members of the former government). In response to requests submitted by former members of Sanacja governments for permission to join the Polish army in France, the Prime Minister openly accused them of 
Poland`s defeat in the September campaign and a devastating impression it made - and it needs to be said here that the Piłsudski adherents themselves were to blame for not doing enough to prevent the public opinion from accepting propagandistic sloganswhich presented the country as entirely unprepared for the impending conflict - created a perfect breeding ground for a propaganda campaign aimed at persuading the Polish people that leaders of the pre-war ruling camp should be brought before Tribunal of State. However, these leaders seemed to be found guilty even before they were brought to justice ${ }^{46}$ and the main goal to be pursued by "The Fact Finding Commission to Enquire into Recent Events in Poland and The Registration Office of the Ministry of Military Affairs" - formally called upon to collect evidence against leaders of the pre-war ruling camp - was to collect evidence against a selected group of political opponents ${ }^{47}$. It was probably only because of

dereliction of duty in preparing the country for war. To his predecessor as Minister of Military Affairs, Sikorski wrote: you are to blame for leaving Poland unprepared for modern type of war, which, as a consequence, makes you also responsible for our defeat in the September campaign. This defeat is not free of disgrace. You General had better stay in BaileHerculane. Poland does not need your service. IPMS Prezydium Rady Ministrów (Internal Cabinet Meeting), sign. 6/a. Korespondencja Wodza Naczelnego z członkami b rządu. Odpowiedź premiera Władysława Sikorskiego na pismo gen. T. Kasprzyckiego z dnia 31 XI 1939 (The Commander-in-Chief`s correspondence with members of former governments. The Prime Minister Władysław Sikorski`s response to a letter from Gen. T. Kasprzycki dated 31 November 1939). There is no doubt that the government that suffered a defeat in a war had to bear political responsibility for the lost campaign. However, requiring the government to step down is not tantamount to charging its Ministers with treason. It also does not have to lead to a resolution that the pre-war ruling elite harmed the country (Such a motion was submitted by conservative politician Stanisław Cat-Mackiewicz. Finally, however, it was not put to vote in the National Council)

${ }^{46} \mathrm{~A}$ diplomatic instruction issued personally by Sikorski and sent out to heads of the Polish diplomatic agencies without the knowledge of Minister of Foreign Affairs can serve as evidence that the pre-September elites were found guilty even before the judge could announce his verdict. The instruction contained the following passus: There is no excuse for foreign, internal, military and economic policy that led to the defeat. The attempt to defend or excuse this policy is to be treated as line of duty offence and will be followed by respective consequences.Archiwum Akt Nowych w Warszawie. Akta Władysława Sikorskiego, sygn. 21[mkf 27604], k. 21. Instrukcja dla kierowników placówek $w$ sprawie propagandy (Polish Central Archives of Modern Records in Warsaw. Władysław Sikorski`s Files, sign. 21 [mcf 27604] Col. 21. Instruction to heads of diplomatic agencies on matters of propaganda).

${ }^{47}$ On the so-called proscription list there appeared the names, among others, of Prime Minister and Minister of Internal Affairs, Felicjan Sławoj-Składkowski; Deputy Minister of Military Affairs, gen. Janusz Głuchowski; Deputy Minister of Military Affairs, gen. Aleksander Litwinowicz; Minister of Foreign Affairs, Józef Beck; Deputy Minister of Foreign Affairs, Jan Szembek; Deputy Minister of Foreign Affairs, Mirosław Arciszewski; Minister of Treasury, Eugeniusz Kwiatkowski; Deputy Minister of Treasury, Tadeusz Grodyński; Deputy Minister of Foreign Affairs, Kajetan Morawski; Minister of Trade and Industry, Antoni Roman; Deputy Minister of Trade and Industry, Adam Rose; Minister of Communications, Juliusz Ulrych; Deputy Minister of Communications, Aleksander Bobkowski; Deputy Minister of Communications, Julian Piasecki; Minister for Post and Telegraphs, Emil Kaliński, Deputy Minister for Post and Telegraphs, Tadeusz Argasiński; Minister of Religious Denominations and Public Enlightenment, Wojciech Świętosławski; Minister of Justice, Wojciech Świętosławski; Minister of Social Security, Marian Zyndram-Kościałkowski; Deputy Minister of Social Security, Tadeusz Garbusiński; Minister of Agriculture and Agrarian Reform, JuliuszPoniatowski; Deputy Minister of Agriculture and Agrarian Reform, Tadeusz 
the reluctance of both the French hosts and the British allies who took a very dim view of the idea of prosecuting men considered responsible for a "national disgrace" and given no chance to testify in their own defense that this idea was dropped ${ }^{48}$. However, the very fact that the Piłsudski adherents were facing a threat of being brought before Tribunal of State once the independence had been restored was used as an argument that they should be excluded from the Polish parliamentary system in exile ${ }^{49}$.

The Bereza Kartuska Detention Camp and the Internment Camps in Cerizey and Rothesay.

Even Marian Kukiel - the historian and the Polish general - who then served as Deputy Minister of War in Sikorski`s government and can be considered as the latter`s greatest apologist stated that "it was even a graver mistake to set up the internment camp in Cerizey for officers who for political reasons were declared unfit to remain on active duty. The same mistake was to be repeated in Britain, causing damage to the image of the government. Of course, there was nothing wrong with the establishment of the camps for the Reserve Officers. What made it so grim an attempt was the use of those camps in the political struggle" ${ }^{, 50}$.

The Internment Camps in Cerizey and Rothesay were patterned on the infamous BerezaKartuska Detention Camp. Its establishment was to a certain extent a response to the assassination of Minister of Internal Affairs Bronisław Pieracki. Most leaders of the ruling camp subscribed to the view that the Polish authorities, faced with so brutal and harrowing an act, could show no sign of weakness. That is why just two days after the assassination the Cabinet of Ministers passed a resolution to establish a detention camp."Under the new regulations - says the scholar who investigated the problem authorities acquired prerogatives vested so far only in judicial institutions. A formal indictment was no longer necessary to arrest (isolate) those whose activities came to be considered as posing a threat to public order. These new regulations gave the authorities a

Wierusz-Kowalski; Deputy Minister of Internal Affairs, BronisławNakiniecznikoff-KLukowski; Deputy Minister of Internal Affairs, WładysławKorsak; See: A. Grzywacz, M. Kwiecień, "SikorszczycykontraSanatorzy 1939-1940 dziejówkonfliktówpolitycznychuchodźstwapolskiego)"[The Sikorski adherents contra Piłsudski followers (On the history of political conflicts among the Polish political exiles], ZeszytyHistoryczne 1999, No 97, p. 127.

${ }^{48}$ Alexis Leger, the Secretary General of the French Ministry of Foreign Affairs who generally approved of the idea of ousting from power people connected with Beck andRydz-Śmigły passed the following judgment upon the idea of isolating and indicting representatives of the pre-war elite: amusing nation, they have came here as beggars and the first thing they do is call for tribunals and concentration camps. Quotation from: M. Hułas, Goście czy intruzi. Rzad polski na uchodźstwie wrzesień 1939 - lipiec 1943, (Guestsorintruders. The Polish government in exile. September $1939-$ July 1943), Warsaw 1996, p. 77.

${ }^{49}$ For more see: A. Adamczyk, Pitsudczycy w izolacji 1939-1954. Studium z dziejów struktur i myśli politycznej (The Piłsudski adherents in isolation. The study of political structures and political thought), Bełchatów 2008, p. 42 and next.

${ }^{50}$ M. Kukiel, Generat Sikorski. Zotnierz i mąż stanu Polski walczacej (General Sikorski. Soldier and statesaman of the fighting Poland, London, p. 96. 
large amount of freedom in deciding whose conduct deserved to be interpreted as harmful to public order and whose did not" ${ }^{\prime 51}$.

The Internment Camps in Cerizey and Rothesay functioned as camps for officers who remained at the disposal of Minister of Military Affairs. However, the role they actually performed was that of detention camp for political opponents ${ }^{52}$. The case of Michat Grażyński reveals a method employed by men connected with Sikorski in the elimination of the opposition of the representatives of the pre-war ruling camp. In the inert-war period Grażyński served as voivode in the region of Silesia. Following the outbreak of the war, he was appointed Minister of Propaganda. Although he was the Reserve Officer holding the rank of Major, this civil servant could hardly be considered a soldier.Having extricated himself from the Romanian trap, being an established expert on Germany, he wished to offer his services either to the President or the Prime Minister. But when he appeared in France, he was ignored. The new authorities reacted when team of instructors of the Polish Scouting and Guiding Association approved his nomination for president of this organization - prior to the outbreak of the war he exercised this function incessantly from 1931. Sikorski and his supporters objected to the idea anxious that Grażyński might prove willing to use his position for indoctrinating young people. To prevent him from doing so, they decided to mobilize him and send him off toCerizey. The defeat of France made the execution of this order impossible. In Great Britain, however, where the Polish military and state authorities were evacuated once Germany had conquered France, the same scenario was applied to Grażyński. And to add insult to this injury, he was put into a subcamp notorious for ordinary criminals, alcoholics and exhibitionists - which is how homosexuals were referred to in official documents ${ }^{53}$. As an additional "precaution"the

51 W. Śleszyński, Obóz odosobnienia w Berezie Kartuskiej 1934-1939 (The detentioncamp in Bereza Kartuska 1934-1939), Biaystok 2003, p. 16; Seealso: J. Polit, Miejsce odosobnienia $w$ Berezie Kartuskiej w latach 1934-1939 (The detention place in Bereza Kartuska in the years 19341939), Toruń 2003, pp. 9-26.

${ }^{52}$ M. Dymarski, „Polskie obozy odosobnienia we Francji i Wielkiej Brytanii w latach 1939-1942” (The Polish Internmentcamps in France and Great Britain in the years 1939-1942). Dzieje Najnowsze 1997, No 3, pp. 115-117; J. Zuziak, „Obozy izolacyjne w Rothesay i Tignabruaich. Z historii Polskich Sił Zbrojnych w Wielkiej Brytanii" (The Internment Camps in Rothesay and Tignabruaich. On the history of the Polish Armed Forces in Great Britain) Mars 1995, No 3, pp. 8990; See also: T. Munnich, "Cerizayi Rothesay" (Cerizay and Rothesay) ZeszytyHistoryczne 1986, No 78, pp. 227-228.

${ }^{53}$ What is important, the decision to send Grażyński off to Rothesay ran counter to the opinion held by Deputy Minister of Military Affairs Marian Kukiel. Kukiel consistently called for freeing Grażyński, indicating that he was a well-known expert on Germany, its system of government, its military and economic affairs. He is the best we have here in Britain. Great Professor. He should be "exploited" in Higher Military School. [IPMS, Marian Kukiel`s Collection, sign. 24/III. Pismo wiceministra spraw wojskowych do NaczelnegoWodza z dnia 29 czerwca 1942 (Deputy Minister of Military Affairs` Letter to Commander-in-Chief dated 29 June, 1942)]There was no response to Kukiel's letters as long as until the Polish authorities were forcedby the English to liquidate the camp. See: Archiwum Instytutu Józefa Piłsudskiego w Londynie (The Archives of Józef Piłsudski Institute in London) [henceforward IJP/L], Col. Polska w drugiej wojnie światowej (Poland in the Second World War), sign. 34, Vol. 1. List wiceministrasprawwojskowych I. Modelskiego do mjr. S. Alley (British Security Service) z 10 III 1942 iodpowiedź z 17 III 1942 (Deputy Minister of Military Affairs I Modelski`s letter to Mjr. S. Alley ((British Security Service)) dated 10, March 1942 and the answer dated 17, March 1942). 
new authorities found it well-advised to entrustsome specially selected officers from the Polish General Staff's Section II (Intelligence)with the task of keeping Grażyński (and Marian Zyndram-Kościałkowski - another minister of the last pre-war Polish Cabinet) under constant surveillance ${ }^{54}$.

The Internment Camps in Cerizey and Rothesay existed for two years. Although the decision to liquidate them was madealready in the Spring of 1942, some officers were permitted to leave these detention places as late as the beginning of 1943. It was the intervention of the British MP H. Morrison that led to the final dissolution of the camps. During one of the parliamentary sessions Harrison said that it was not a good idea to forbid some Poles to take part in the struggle for independence of their own country and expressed the opinion that political vendetta was highly unlikely to help the war effort ${ }^{55}$. A direct pressure applied on Sikorski by the British ally forced him to wind up the camps. The scholar who dealt with the problem of the camps wrote: "Bute was different fromBereza. People who did their time in the camp were not beaten or put behind barbed wires, but political (and personal) goals to be achieved by means of it were quite similar(...)Sikorski who felt confident of his position and had the British support to be relied on for conducting his policy turned the Internment Camps into a weapon with which to solve his political problems(...) However,neither Churchill nor the British society were willing to countenance the use of so undemocratic methods - especially by the politician who had amassed such an unprecedented executive power" ${ }^{\prime 56}$.

Actions in violation of the Constitution.

Embroiled in violent political battles, Piłsudski and his followers often laid themselves open to chargesof violating the Constitution. The coup detat which they carried out in May 1926was usually taken to constitute the most telling example of constitutional violation. There is of course no doubt that the Piłsudski adherents strove to seize power. It is also quite obvious that the perpetrators of the coup detat struck a blow to the legal system. What, however, is still open to debate is whether the Marshal Piłsudski really intended to violate the Constitution ${ }^{57}$ or infringe its fundamental principles ${ }^{58}$.

\footnotetext{
${ }^{54}$ On the problem of the activities of the Polish General Staff Section II in the internment camps see: S. Mękarski, Zapiski z Rothesay1940-1942 (Jottings from Rothesay 1940-1942). LondonPiotrkówTryb 2003, p. 194 and next. IJP/L Collection of Marian Zyndram Kościałkowski, sign. 98, File Okres drugiej wojny światowej (The period of the Second World War). IPMS, Prezydium Rady Ministrów, (Inner Cabiet) sign. PRM.K 63, k. 93.

${ }^{55}$ Poland in the British Parlia ment 1939-1945, vol. II, New York 1959, pp.41-42.

${ }^{56}$ A. Dymarski, Polskie obozy...(The Polish Internment Camps...), pp. 125-126.

${ }^{57}$ The thesis put forward by WaldemarParuch deserves to be paid attention to in the context under discussion. The author claims that in May 1926 the change in the system of government of the Polish Republic had become necessary and Piłsudski and his adherents decided to carry out coup d'etat when all other ways of seizing power had run out. Even if at first the Piłsudski adherents made use of extra-legal means, then they were quick to legalize the situation that had emerged after coup detat. W Paruch, Zamach majowy 1926 - przesłanki i konteksty ustanowienia autorytarnego system politycznego w II Rzeczypospolitej (The Coup d`Etat in May 1926 - premises and contexts involved in establishing the authoritarian system of government in the Second Republic in Poland), [w:] Zamach stanu Józefa Piłsudskiego 1926 (Józef Piłsudski`s Coup d’Etat of May 1926), ed. by M. Sioma, Lublin 2007, p. 347.

${ }^{58}$ M. Suleja disproved the interpretation that the then Minister of Military Affairs gen Lucjan Żeligowski was involved in activities intended to pave the way for the seizure of power by
} 
Sikorski, by contrast, often and quite deliberately put himself above the Constitution. The so-called Sikorski-Majski treaty of May, 30, 1941 -both its stipulations and the way in which it was concludedcan serve as the most evident example of it. Sikorski s decision to get himself directly involved in the negotiations and put his signature under the treaty while it was only the Soviet ambassador to the UK that did the same on behalf of the Soviet Union - unnecessarily showed the existing inequality between the two negotiating parties $^{59}$. Some terms of the treaty were clearly at variance with the Polish reason of state $^{60}$. However, the most important thing that needs to be emphasized in the attempt to elucidateSikorski`s political temper, his democratic or undemocratic ways is the fact that during the negotiations he exercised prerogatives vested in President, thus breaking the spirit as well as the letter of the Constitution. Having no license from the President to sign the treaty whose article 5 stipulated that the treaty was supposed to come into effect immediately without being ratified ${ }^{61}$, Sikorski violated three key provisions of the Constitution: article $12^{62}$ of the Constitution of $1935^{63}$ as well as some terms of the Paris agreement.

Piłsudski. Suleja thus contested the opinions held by such scholars as A. Garlicki (JózefPiłsudski 1876-1935, Warsaw 1990, pp. 333-334); A. Czubiński (Przewrótmajowy 1926 ((May Coup d`Etat of 1926)), Warsaw 1989, pp. 161-162); C. Brzoza and A Sowa, (HistoriaPolski 1918-1945 ((The History of Poland 1918-1945)), Cracov 2006, pp. 178-179). See also: W. Paruch, Przewrótmajowy w historiografii (The May Coup d'Etat in historiography), [w:] Zamach stanu (The Coup d'Etat)..., pp. 14-15.

59 The Prime Minister was one of the signatories while the ambassador served as his partner. There were no impediments (except of course for diplomatic pressure exercised mainly by the English) that stood in the way of having the treaty signed by heads of both governments, or on the part of Poland the treaty could have been first initialed by a diplomat equal in rank to Majski (it was out of the question for the treaty to be signed by the Polish Minister of Foreign Affairs, since August Zalewski was among those who were opposed to signing this treaty) and then officially signed during Siorski`s visit to Moscow.

${ }^{60}$ The parts of the Sikorski Majski treaty that came to be regarded as remaining in conflict with the Polish reason of state were: The Article 1 of the treaty which stipulated that the Soviet-German agreements concluded in 1939 and concerning territorial changes in Poland were no longer valid (which did not amount to restoring borderline status quo ante bellum between Poland and the Soviet Union, and that was exactly the goal the President and some Polish political circles wanted to achieve). The Protocol additional to the treaty in question was also interpreted as out of keeping with the Polish reason of state. It included the following stipulation: once diplomatic relations between the two countries are restored, the Soviet government grants amnesty to all Polish citizens currently imprisoned in the Russian territory either as prisoners-of-war or on other grounds.See: J. Kumaniecki, Stosunki Rzeczypospolitej Polskiej z państwem radzieckim 1918-1943. Wybór dokumentów (Poland`s relations with the Soviet Union 1918-1943. The selection of documents), Warsaw 1991, pp. 244-245.

${ }^{61}$ Ibidem, p 245.

${ }^{62}$ I am talking about the following paragraph of the Article which reads: e)[the President] represents the Republic towards the outside world, meets and hosts representatives from other states and sends representatives of the Polish Republic to other states; f) decides on matters of war and peace; $g$ ) concludes and ratifies agreements with other states. W Rostocki, Pięćdziesiatlat (Fifty years)..., p. 303.

${ }^{63}$ The view that Sikorski`s activities violated Constitution is shared by both experts on institutional and legal matters (W. Rostocki, Pięćdziesiąt lat ((Fifty years))..., pp. 146-162; D. Górecki, Polskie naczelne władze państwowe na uchodźstwie w latach 1939-1990 ((The Polish authorities in exile in 
He was foundhardly convincing when - during the crisis for whose outbreak he was clearly to blame - he tried to justify his conduct by his willingness to defend democracy and his commitment to make sure that those who showed no respect for the Constitution and whose mistakes brought the country to the edge of an abyss ${ }^{64}$ would not come back to power. Even those politicians who wereSikorski`s stalwart supportersmade no secret of their beliefsthat the Prime Minister acted in defiance of the Constitution, was overconfident, and driven by an authoritarian temper ${ }^{65}$.

\section{SIKORSKI - THE AUTHORITARIAN POLITICIAN. IN PLACE OF CONCLUSIONS}

The way in which Sikorski and his policy are remembered and judged by the vast majority of Poles owes much to the legend that has surrounded him since his tragic and mysterious death and has little to do withhis real accomplishments ${ }^{66}$. Olgierd Terlecki made the case that Sikorski`s image embedded in society`s collective memory was not the result of a rational judgment but was given rise to by extraordinary circumstances Sikorski had found himself in. The publicist stated: "It was still during his lifetime that he became a formidable figure made of bronze and that was exactly the way he was looked upon by his countrymen made to suffer a torment of barbarous occupation and by Polish soldiers ready to struggle for freedom in every corner of the world. They saw in him the person they wanted to see: a statesman who commanded respect among foreign politicians, a soldierwith a commitment to fight and defeat the enemy, and a reformer capable of rebuilding the country once the war was over" ${ }^{, 67}$

Sikorski succeeded in passing himself off as a true democrat by throwing into doubt achievements of the Piłsudski adherents and by contesting the political system they created. In truth, the post-September Prime Minister did nothing to introduce a democratic style of exercising power. To make things worse, in the exercise of power he quite deliberately made use of the same instruments once made use of by his predecessors, thus abusing it the same way they did. One is tempted to think that Sikorski was unable to liberate himself from the influenceexerted on him by Józef Piłsudski. As a statesman and Prime Minister he failed to elaborate a model of exercising power different from that established by Piłsudski whom Sikorski admired and hated at the same time. Both his

the years 1939-1990)), Warsaw 2002, p. 39) as well as those specializing in the history of the Soviet-Polish relations (See: W. Materski, Na widecie. Rzeczpospolita wobec Sowietów 1918-1943 ((On the look-out. The Second Republic towards the Soviets 1918-1943)), Warsaw 2005, p. 614.)

${ }^{64}$ Quotation from: W. Rostocki, Pięćdziesiatlat (Fifty years)..., p. 156.

${ }^{65}$ Gen. Józef Haller who was closely connected with Sikorski wrote: it needs to be said here that this time too Sikorski created fait accompli, taking no notice of possible consequences. J. Haller, Pamiętniki (Memoirs), London 1964, p. 322.

${ }^{66}$ A. Adamczyk, „Sprawa Sikorskiego” a nośniki pamięci historycznej. Między politologia, polityka historyczna a historia polityczna (,The Sikorskie case” and carriers of historicalmemory. Between politology, historical policy and politicalhistory), [w:] Od Rosji po Bliski Wschód. Studia historyczne z XX wieku (From Russia to the Middle East. Studies on the history of the $20^{\text {th }}$ century), ed. by D. Rogut, Zelów 2010, pp. 151-173.

${ }^{67}$ O Terlecki, Generat ostatniej legendy. Rzecz o WtadystawieSikorskim (General of the last legend. On Władysław Sikorski), Chicago 1976, p. 322. Terlecki states clearly that Sikorski nie był postacią ze spiżu, jaka chciał w nim widzieć naród (he was not made of bronze and was not the man the nation thought he was).Ibidem, p. 324. 
contemporaries $^{68}$ and those born later ${ }^{69}$ were aware of this. In truth, he may have considered the model elaborated by Piłsudski (coexistence of "weak" president with those in whose hands rested real power) as an ideal worth copying. And but for the escalation of the conflict with the "wraith" of Piłsudski and his adherents, he would have been likely to succeed in following the late Marshal`s example - after all the President Raczkiewicz`s deteriorating health made this scenario quite probable ${ }^{70}$. The so-called July crisis of 1940 when there took place a clash between Sikorski and Piłsudski adherents which resulted in debilitating both sides of this conflict made it necessary for Sikorski - whose power rested on a poor powerbase - to rely for the exercise of power on cooperation with traditional political parties ${ }^{71}$. Although, as has already been stated, Sikorski never eschewed his authoritarian tendencies, in 1940 he actually lost any chance to rise to a position once held by the Marshal Piłsudski.

\section{BIBLIOGRAPHY}

[1] Adamczyk A., „Sprawa Sikorskiego” a nośniki pamięci historycznej. Między politologia, polityka historyczna a historia polityczna („The Sikorskie case” and carriers of historicalmemory. Betweenpolitology, historical policy and politicalhistory), [w:] Od Rosji po Bliski Wschód. Studiahistoryczne z XX wieku (From Russia to the Middle East. Studies on the history of the $20^{\text {th }}$ century), ed. by D. Rogut, Zelów 2010.

[2] Adamczyk A., Generat dywizji Sławoj Felicjan Składkowski 1885-1962. Zarys biografii politycznej (Major general. Sławoj Felicjan Składkowski 1885-1962. The out line of political biography), Torun 2001.

[3] Adamczyk A., Pitsudczycy w izolacji 1939-1954. Studium z dziejów struktur i myśli politycznej (The Piłsudski adherents in isolation. The study of political structures and political thought), Bełchatów 2008.

[4] Bargiełowski D., Po trzykroć pierwszy. Michał Tokarzewski-Karaszewicz. Generat broni. Teozof. Wolnomularz. Kaptan Kościoła Liberalno-katolickiego (Three Times the First. MichałTokarzewski-Karaszewicz. Lieutenant General. Theosopist. Freemason. The Priest of the Liberal-Catholic Church), Warsaw 2001.

\footnotetext{
${ }^{68}$ Kajetan Morawski argued that Sikorskiwas a slave to the myth to be measured up to by others and created by others. Subconsciously, he wastormented with the idea of great political prominence to which he tried to rise and which only the Marshal Pitsudski had managed to achieve.K. Morawski, Wspólna droga z Rogerem Raczyńskim. Wspomnienia (En route with Roger Raczyński. Recollections), Poznań 1998, p. 216.

${ }^{69}$ Terlecki whom I have already quoted argued that: it is the myth of the Marshal Pitsudski under whose sway Sikorski remained that can account for many of the latter's decisions. In taking them Sikorski either blindly followed the path once frequented by his great predecessor - which was usually to no avail under changed circumstances - or embarked on a bitter polemic with him, expressing the voice of protest against the policy conducted by the Marshal before the war.The myth was to beset Sikorski even after his death. When the coffin with Sikorski`s body displayed in the building where the Polish Cabinet met was approached by the delegation of the Norwegian army, its leader announced that by the order of the king of Norway the Norwegian War Cross is awarded to a great Polish soldier...Józef Pitsudski.O. Terlecki, op. cit, p. 323.

${ }^{70}$ See: M. Drozdowski, Władysław Raczkiewicz. Prezydent RP (Władysław Raczkiewicz. President of the Polish Republic), Vol. 2, Warsaw 2002, pp. 5-163.

${ }^{71}$ M. Dymarski, Stosunki wewnętrze...(Internal relations), pp. 112 and next.
} 
[5] Cieślikowski Z., Tajemnice śledztwa KO 1042/27. Sprawa generała Włodzimierza Ostoi-Zagórskiego, (The secrets of investigation KO 1042/27. The case of gen. Włodzimierz Ostoja-Zagórski), Warszawa 1997.

[6] Drozdowski M., Władysław Raczkiewicz. Prezydent RP (Władysław Raczkiewicz. President of the Polish Republic), Vol. 2, Warsaw 2002.

[7] Dymarski M., „Notatnik rumuński gen. Władysława Sikorskiego, wrzesień 1939” (Gen. Władysław Sikorski’s Romanian Notebook, Septemeber 1939), Teki Historyczne 1999, Vol. XXII.

[8] Dymarski M., „Polskie obozy odosobnienia we Francji i Wielkiej Brytanii w latach 1939-1942" (The Polish Internmentcamps in France and Great Britain in the years 1939-1942). Dzieje Najnowsze 1997, No 3.

[9] Dymarski M., Stosunki wewnętrzne wśród polskiego uchodźstwa politycznego i wojskowego we Francji $i$ Wielkiej Brytanii 1939-1945 (The relations among the Polishpolitical and militaryexiles in France and Great Britain 1939-1945), Wrocław 1999.

[10] Dyplomata w Paryżu. Wspomnienia i dokumenty Juliusza Eukasiewicza, ambasadora Rzeczypospolitej Polskiej (Diplomat in Paris. The recollections and documents of Juliusz Łukasiewicz, Ambasador of the Polish Republic), ed. by W. Jedrzejewicz, H. Bułhak, London 1989.

[11] Garlicki A., ,Mitomani i maniacy” (Maniacs and Mythomanias), „Polityka” No 5(31 I 2009).

[12] Garliński J., Politycy i żołnierze (Politicians and soldiers), Warsaw 1991.

[13] Górecki D., Polskie naczelne władze państwowe na uchodźstwie w latach 1939-1990 (The Polish authorities in exile in the years 1939-1990), Warsaw 2002.

[14] Grzywacz A., Kwiecień M., "Sikorszczycy kontra Sanatorzy 1939-1940 (Z dziejów konfliktów politycznych uchodźstwa polskiego)"[The Sikorski adherents contra Piłsudski followers (On the history of political conflicts among the Polish political exiles], Zeszyty Historyczne 1999, No 97.

[15] Grzywacz A., Kwiecień M., „Rada Narodowa Rzeczypospolitej Polskiej w walce z sanataorami 1939-1941" (The National Council of the Polish Republic in its struggle against the representatives of the Sanacja Regime 1939-1941), Zeszyty Historyczne 2000, Vol. 131

[16] Habielski R., Kryzysy polityczne 1947 i 1954 (Politicalcrises of 1947 and 1954), [w:] Warszawa nad Tamiza. Z dziejów polskiej emigracji politycznej po II wojnie światowej (Warsaw on the River Thames. The history of the Polish political emigration after the Second World War), ed. by A. Friszke, Warszawa 1994.

[17] Haller J., Pamiętniki (Memoirs), London 1964.

[18] Hułas M., Goście czy intruzi. Rząd polski na uchodźstwie wrzesień 1939 - lipiec 1943, (Guestsorintruders. The Polish government in exile. September 1939 - July 1943), Warsaw 1996.

[19] Korpalska W., Władysław Eugeniusz Sikorski. Biografia polityczna (Władysław Eugeniusz Sikorski. Political Biography), Wrocław 1988

[20] KowalskiP., Generat brygady Włodzimierz Ostoja-Zagórski 1882-1927. Biografia, (Brygadier General Włodzimierz Ostoja-Zagórski 1882-1927. Biography) Toruń 1997.

[21] Kukiel M., Generat Sikorski. Zotnierz $i$ maż stanu Polski walczacej (General Sikorski. Soldier and statesaman of the fighting Poland, London.

[22] Kumaniecki J., Stosunki Rzeczypospolitej Polskiej z państwem radzieckim 1918 1943. Wybór dokumentów (Poland`s relations with the Soviet Union 1918-1943. The selection of documents), Warsaw 1991.

[23] Materski W., Na widecie. Rzeczpospolita wobec Sowietów 1918-1943 (On the lookout. The Second Republic towards the Soviets 1918-1943), Warsaw 2005. 
[24] Mękarski S., Zapiski z Rothesay1940-1942 (Jottings from Rothesay 1940-1942). London-PiotrkówTryb 2003.

[25] Michnik A., "Wasz prezydent nasz premier" (Your President, our Prime Minister), GazetaWyborcza, No 40 (3 July 1989).

[26] Morawski K., Wspólna droga z Rogerem Raczyńskim. Wspomnienia (En route with Roger Raczyński. Recollections), Poznań 1998.

[27] Munnich T., "Cerizayi Rothesay" (Cerizay and Rothesay) Zeszyty Historyczne 1986, No 78.

[28] Paczkowski A., Mikołajczyk, czyli klęska realisty (Mikołajczyk or a realist’s defeat), Warszawa 1991.

[29] Panecki T., Generat broni Władysław Eugeniusz Sikorski - 1888-1943 (Lieutenant General. Władysław Eugeniusz Sikorski 1888-1943), Warszawa 1993.

[30] Paruch W., Myśl polityczna obozu Pitsudczykowskiego 1926-1939 (Political thought of the Piłsudski camp 1926-1939), Lublin 2005.

[31] Patelski M.,Generat broni Tadeusz Jordan-Rozwadowski. Żotnierz i dyplomata (Lieutenant General Tadeusz Jordan Rozwadowski. Soldier and dyplomat), Warszawa 2002.

[32] Pestkowska M., Kazimierz Sosnkowski, Wrocław 1995.

[33] Pobóg-Malinowski W.,Najnowsza historia poolityczna Polski. Okres 1939-1945 (Modern political history of Poland. The period 1939-1945), Vol. 1, Gdańsk 1989.

[34] Polit J., Miejsce odosobnienia w Berezie Kartuskiej w latach 1934-1939 (The detention place in Bereza Kartuska in the years 1934-1939), Torun 2003.

[35] Polska w latach 1944-1989. Dokumenty i materiaty, oprac. A. Hutniewicz, A. Wątor, (Poland in the years 1944-1989. Documents and materials, ed. By A. Hutniewicz, A. Wątor), Szczecin 1988.

[36] Rostocki W., Pięćdziesiąt pięć lat mocy obowiąującej konstytucji kwietniowej. Ustrój władzy państwowej w ustawie zasadniczej i praktyce (Fifty five years of the operation of the April Constitution. The system of state authorities in the Basic Law and in practice), Lublin 2002.

[37] Rostocki W., Stosowanie Konstytucji Kwietniowej w czasie II wojny światowej (The application of the April Constitution during the Second World War), Lublin 1988.

[38] Sioma M., Felicjan Stawoj Składkowski. Żotnieżi polityk (Felicjan Sławoj Składkowski. Soldier and politician), Lublin 2005.

[39] Składkowski F.S., Strzępy meldunków (The scraps of reports), Warsaw 1988.

[40] Skrzynecki P. (L. Brzoza), „Kiedy umierał prezydent Raczkiewicz” (When the President Raczkiewicz was dying), Zeszyty Historyczne 1989, No 87.

[41] Śleszyński W., Obóz odosobnienia w Berezie Kartuskiej 1934-1939 (The detentioncamp in Bereza Kartuska 1934-1939), Białystok 2003.

[42] Stroński S., „I. Paderewski - śmierć na posterunku” (I. Paderewski - A line of dutydeath) Dziennik Polski i Dziennik Żotnierza, London, No 160 (6 July 1951).

[43] Tarka K., „Rozgrywka nad trumną. Sprowadzenie prochów Władysława Sikorskiego do Polski” (A show down over the coffin. The bringing of Władysław Sikorski`s mortal remains to Poland), Dzieje Najnowsze 2003, No 3.

[44] Terlecki O., Generat ostatniej legendy. Rzecz o Władysławie Sikorskim (General of the last legend. On Władysław Sikorski), Chicago 1976.

[45] Turkowski R., Parlamentaryzm polski na uchodźstwie 1945-1972 w okresie rozbicia emigracji politycznej $w$ Londynie (The Polish parliamentarism in exile 1945-1972 during the disunity in the Polish political emigration in London), Warszawa 2006.

[46] Zamach stanu Józefa Pitsudskiego 1926 (Józef Piłsudski`s Coup d’Etat of May 1926), ed. by M. Sioma, Lublin 2007.

[47] Zuziak J., „Obozy izolacyjne w Rothesay i Tignabruaich. Z historii Polskich Sił Zbrojnych w Wielkiej Brytanii" (The Internment Camps in Rothesay and 
Tignabruaich. On the history of the Polish Armed Forces in Great Britain) Mars 1995, No 3.

[48] "Ostatni lot" (The last flight), Polityka No 33/1889 (25, September, 1993).

[49] „Poradnik Propagandysty” (Self-Help Book of the Propagandist) 1946, No 3(14).

\section{GENERAŁ WŁADYSŁAW SIKORSKI JAKO PREMIER RZADU RP NA UCHODŹSTWIE. SZCZERY DEMOKRATA CZY SPADKOBIERCA AUTORYTARYZMU}

Paradoksalnie pamięć zbiorowa o gen. Sikorskim, jak również oceny jego politycznych postaw oparte zostały w przeważającej mierze nie na jego faktycznych dokonaniach lecz na legendzie, wzmocnionej dodatkowo przez śmierć w tragicznych i dość niejasnych okolicznościach. Opinia o generale, jako o polityku-demokracie, wynikała przede wszystkim z przeprowadzanej przez Sikorskiego negacji dokonań poprzedników, jak też firmowanego przez nich systemu politycznego. Tymczasem powrześniowy premier faktycznie nie zrobił nic, aby przeciwstawić się autorytarnemu sposobowi sprawowania władzy w państwie. Nie sposób nie odnieść wrażenia, iż Sikorski nie mógł, ale też i nie miał pomysłu na to, jak wyzwolić się spod - przemożnego, jak się okazało - wpływu Józefa Piłsudskiego. Jako premier, minister i mąż stanu nie potrafił pokusić się o wypracowanie jakiegokolwiek alternatywnego modelu sprawowania władzy, wzorując się na postaci, która jednocześnie podziwiał, jak i szczerze nienawidził.Jak się wydaje również, model który wypracował Piłsudski (tj. koegzystencja „słabego Prezydenta” z faktycznym czynnikiem decyzyjnym), mógł stanowić dla Sikorskiego pewien ideał. Prawdopodobnie byłaby to konstrukcja możliwa do urzeczywistnienia gdyby nie eskalacja konfliktu z ,widmem Piłsudskiego" i z adherentami Wielkiego Marszałka. Tzw. kryzys lipcowy 1940 r., podczas którego doszło do zwarcia między piłsudczykami i premierem, faktycznie doprowadził do osłabienia obu stron konfliktu i skazał - dysponującego fasadowym zapleczem Sikorskiego, na oparcie się o współpracę z „tradycyjnymi” stronnictwami politycznymi. Choć do końca swych rządów premier skłaniał się ku rozwiązaniom autorytarnym, praktycznie już w 1940 r. bezpowrotnie zaprzepaścił szansę na osiągnięcie pozycji w państwie, jaką przed 1935 r. zdobył sobie Józef Piłsudski.

Slowa kluczowe: autorytaryzm, demokracja, konflikt polityczny, władza polityczna, historia Polski.

DOI:10.7862/rz.2016.hss.16

Przesłano do redakcji: marzec 2016

Przyjęto do druku: czerwiec 2016 